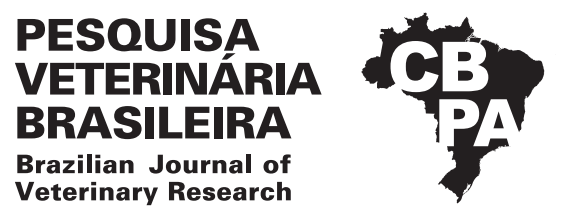

\title{
Comparison of two collection methods to determine protodioscin concentrations in Brachiaria spp. and to monitor Brachiaria spp. poisoning ${ }^{1}$
}

\author{
Gleice K.A. Melo ${ }^{2}$ (D), Westerlly J. Silva ${ }^{2}$, Rayane C. Pupin ${ }^{3}$, Rubiane F. Heckler², \\ Lucimara M. Nonato ${ }^{2}$, Camila C.B.F. Ítavo ${ }^{2}$, Valquíria B.N. Ferreira ${ }^{4}$ \\ and Ricardo A.A. Lemos ${ }^{2 *}$ (D)
}

\begin{abstract}
Melo G.K.A., Silva W.J., Pupin R.C., Heckler R.F., Nonato L.M., Ítavo C.C.B.F., Ferreira V.B.N. \& Lemos R.A.A. 2019. Comparison of two collection methods to determine protodioscin concentrations in Brachiaria spp. and to monitor Brachiaria spp. poisoning. Pesquisa Veterinária Brasileira 39(9):710-714. Laboratório de Anatomia Patológica, Faculdade de Medicina Veterinária e Zootecnia, Universidade Federal de Mato Grosso do Sul, Av. Senador Filinto Muller 2443, Campo Grande, MS 79074-460, Brazil. E-mail: ricardo.lemos@ufms.br

The objective of this study was to evaluate the methods of collecting Brachiaria spp. (Simulated Grazing vs. Total Collection) for the determination of protodioscin concentrations and to monitor the intoxication in sheep susceptible and resistant to poisoning by Brachiaria spp. The collection of Brachiaria spp. was done through two different methods. The first one consisted in throwing a metallic square at 10 random picket points. The second was performed simulating, with the hands, the grazing behavior of sheep. The leaf blades obtained by the two methods were conditioned in a forced ventilation oven. The extraction and quantification of protodioscin from the dry milled plant material was done by reverse-phase high-performance liquid chromatography (HPLC). The collections were carried out at three stages of the life of experimental lamb (suckling, rearing, and finishing). The lambs were divided into resistant and susceptible to intoxication by Brachiaria spp. The criterion for a lamb to be considered sensitive was to present some clinical signs at some stage of its life. No significant differences were observed between the general averages of the two collections when the evaluation was done in the whole period. However, a significant difference was found at the onset of the clinical signs. The concentrations of protodioscin in this period were higher in Brachiaria spp. collected by the simulating grazing method. Both methodologies were efficient to determine the level of protodioscin in the pastures of Brachiaria spp. However, during the periods when the outbreaks occurred, the simulated grazing method was more reliable.
\end{abstract}

INDEX TERMS: Collection methods, protodioscin concentrations, Brachiaria spp., poisoning, hepatogenic photosensitization, simulated grazing, toxic plants, small ruminants.

RESUMO.- [Comparação entre dois métodos de coleta para determinar as concentrações de protodioscina em Brachiaria spp. e monitorar a intoxicação por Brachiaria spp.] Objetivou-

\footnotetext{
${ }^{1}$ Received on April 6, 2019.

Accepted for publication on April 18, 2019.

Doctoral Research with CAPES financial support.

${ }^{2}$ Graduate Studies Program in Animal Science, Faculdade de Medicina Veterinária e Zootecnia, Universidade Federal de Mato Grosso do Sul (UFMS), Av. Senador Filinto Muller 2443, Campo Grande, MS, 79070-900, Brazil. *Corresponding author: ricardo.lemos@ufms.br

${ }^{3}$ Graduate Studies Program in Veterinary Science, Faculdade de Medicina Veterinária e Zootecnia, Universidade Federal de Mato Grosso do Sul (UFMS), Av. Senador Filinto Muller 2443, Campo Grande, MS, 79070-900.

${ }^{4}$ Instituto Federal de Mato Grosso do Sul, Campus Aquidauana, Rua José Tadao Arima 222, Aquidauana, MS 79200-000, Brazil.
}

se avaliar dois métodos de coleta de Brachiaria spp. (Pastejo Simulado vs Coleta Total) para determinação das concentrações de protodioscina e efetuar o monitoramento da intoxicação em rebanhos sensíveis e resistentes à intoxicação por Brachiaria spp. Foram realizadas coletas de Brachiaria spp. através de duas metodologias. A primeira consistiu em fazer o lançamento de um quadrado metálico em 10 pontos aleatórios do piquete. A segunda foi realizada simulando com as mãos o comportamento de pastejo dos ovinos. As lâminas foliares obtidas pelas duas metodologias foram acondicionadas em estufa de ventilação forçada. 0 material seco e moído foi encaminhado para extração e quantificação da protodioscina por cromatografia líquida de alto desempenho (HPLC) de fase reversa. As coletas foram realizadas em três fases de 
vida dos cordeiros (cria, recria e terminação). Os cordeiros foram divididos em resistentes e sensíveis a intoxicação por Brachiaria spp. 0 critério para o ovino ser considerado sensível foi apresentar algum sinal clínico da intoxicação em alguma fase de sua vida. Não foram observadas diferenças significativas entre a média geral das duas coletas quando a avaliação foi feita no período total. Porém, foi observada diferença significativa no período de aparecimento dos casos. As concentrações de protodioscina neste período foram superiores pelo método do pastejo simulado. Ambas as metodologias mostraram-se eficientes para determinação da concentração da protodioscina nas pastagens de Brachiaria spp. No entanto, nos períodos em que ocorreram os surtos, o método do pastejo simulado foi mais fidedigno.

TERMOS DE INDEXAÇÃO: Métodos de coleta, protodioscina, Brachiaria spp., intoxicação, fotossensibilização hepatógena, pastejo simulado, plantas tóxicas, pequenos ruminantes.

\section{INTRODUCTION}

Brachiaria spp. grasses are the main forages used in the central-western and southeastern regions of Brazil for ruminant forage (Porto et al. 2013), but are potentially toxic and cause economic losses due to death and reduced productive performance (Riet-Correa et al. 2011, Mustafa et al. 2012, Porto et al. 2013, Pupin et al. 2016). Brachiaria toxicity is due to lithogenic steroidal saponins contained in this grass and protodioscin has been the main saponin found in Brachiaria spp. (Riet-Correa et al. 2011). There are no well-defined methodologies for harvesting Brachiaria for determining protodioscin concentrations in this forage. There are reports of the levels of protodioscin determination in Brachiaria collected from different parts of the plant during an outbreak of poisoning in sheep, (Brum et al. 2007). In another study, protodioscin concentrations were evaluated at 28-day intervals according to the maturation stage of the plant (Faccin et al. 2014). However, the methodologies used did not take into account the grazing habits of sheep.

Considering that sheep consume the young leaves in preference over the senescent stems and leaves, that is, the whole forage canopy, and that the selected forage has different chemical and anatomical characteristics from the herbage available in the pasture (Goes et al. 2003, De Paula et al. 2009), the use of simulated grazing is the most representative method for collection when more reliable information is sought (Weir \& Torell 1959, Cook 1964, Goes et al. 2003). This collection methodology could be applied with advantages over those previously used to evaluate protodioscin concentrations in Brachiaria spp.

The objective of this study was to compare two harvesting methodologies to determine the concentrations of protodioscin and simultaneously monitor the clinical course of the poisoning in Brachiaria-susceptible and Brachiaria-resistant lambs poisoned at three stages of their development.

\section{MATERIALS AND METHODS}

The experiment was carried out at the in the municipality of Campo

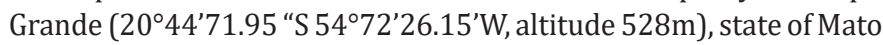
Grosso do Sul (MS) Brazil. The meteorological data were obtained from the National Institute of Meteorology (INMET 2015)/Center for
Monitoring Climate and Water Resources of MS (Cemtec-MS)/Agency for Agrarian Development and Rural Extension (Agraer).

Collections of Brachiaria spp. were done from May to December, 2014 and from January to February, 2015 to determine the concentrations of protodioscin. The collections were performed every 28 days, using two different methods. The first one (total collection) consisted in casting a metallic square of $0.25 \mathrm{~m}^{2}(0.5 \times 0.5 \mathrm{~m})$ in 10 random points representative of the forage canopy (McMenniman 1997) while sheep were grazing. The cuts were carried out close to the ground with the aid of metallic scissors. After cutting of all aerial parts, the samples were weighed individually, and then the plant material was homogenized and quartered, in order to obtain a representative sample from the picket. Subsequently, the morphological separation of the leaf blade, stem + sheath and senescent material (leaf blades and stems with progressive yellowing, visible darkening, and dehydration, characterizing the senescence phase of the tiller) were performed.

The second method consisted in simulate manually the movements of a sheep grazing (simulated grazing). The grazing behavior of the lambs were observed to determine the height and parts of the plant consumed, in order to obtain samples similar to those consumed by sheep. The grasping of the grass by the animal was reproduced with the hands, and 100 grams of the sample cut with the aid of a pocketknife (Cook 1964).

The leaf blades collected by the two methodologies were conditioned in a forced ventilation oven at $55^{\circ} \mathrm{C}$ for 72 hours, crushed in a Willey mill with $1 \mathrm{~mm}$ mesh sieves and analyzed for dry matter (\% DM). The extraction and quantification of protodioscin by reverse-phase high-performance liquid chromatography (HPLC) was performed according to a previously described methodology (Ganzera et al. 2001).

The plant samples were collected in pastures with a history of intoxication by Brachiaria spp. in sheep. During the experimental period, two groups were simultaneously observed for intoxication. The first was identified as sensitive, initially formed by two sheep and one ram. The second group was identified as resistant and consisted initially of three sheep and one ram. Sheep presenting clinical signs of Brachiaria spp. poisoning at some stage of their lives were considered sensitive. The resistant sheep were those that presented no clinical signs of Brachiaria spp. poisoning at any stage of their lives (Pupin et al. 2016).

The progeny of these two groups, 9 sensitive and 4 resistant lambs, were allocated in the same pickets, where the samples were collected. The experimental period was divided according to the life stage of the lambs, described as suckling, rearing and finishing. During the suckling stage, from May to July, 2014, the lambs and their mothers remained in continuous grazing on pickets formed by Brachiaria brizantha. On August 2014, the lambs were weaned and transferred to a picket containing Brachiaria decumbens, remaining there (rearing stage) in continuous grazing management until November 2014. The finishing stage began on December 2014, when the sheep entered in their reproductive life, remaining under the same management of continuous grazing in the pastures of $B$. decumbens. Clinical manifestations and Brachiaria collections were monitored until February 2015. Clinical course, necropsy and histopathological findings caused by Brachiaria spp. poisoning in sheep of the current study are described elsewhere (Pupin et al. 2016).

The Mann-Whitney test at $5 \%$ significance compared the results of the protodioscin values obtained by the two applied methodologies o plant collection. 


\section{RESULTS}

The concentration of protodioscin (\% dry matter - DM) in the samples collected through the selective grazing method ranged from 0.42 to $1.81 \%(1.020 \pm 0.448)$. In plant material sampled by total collection, the concentration ranged from 0.24 to $1.22 \%(0.773 \pm 0.328)$. There was no significant difference between the general means of the two sampling methods by the Mann-Whitney test $(\mathrm{P}>0.05)$ when the evaluation was made for the whole experimental period. However, a significant difference $(\mathrm{P}<0.05)$ was observed by the same test from July to November of 2014 (Table 1).

Cases of intoxication were observed in the lambs of the sensitive herd. Of the nine lambs monitored, eight presented clinical signs of intoxication by Brachiaria spp. After reintroduction of the lambs in the pastures, clinical recurrences were detected and the lambs were again hospitalized (Table 1). The four lambs of the resistant herd were monitored daily during the three phases of the experimental period and none of them presented clinical signs of intoxication.

In the suckling stage (May-July, 2014), no cases of poisoning were observed in lambs in B. brizantha pastures. However, clinical signs of Brachiaria poisoning, including relapses, were observed in all months of the rearing stage (August-November, 2014). In the finishing stage (December 2014-February, 2015) only one relapse was recorded (Table 1).

In the suckling stage (May-July, 2014), when no lamb showed clinical signs of Brachiaria poisoning, protodioscin concentrations were similar between selective grazing and total collection. Likewise, in the termination phase when a relapse was recorded in February 2015, protodioscin concentrations did not differ between the methodologies studied (Table 1).

However, in July 2014 (a month prior to the outbreak) the protodioscin concentrations of the simulated grazed samples were significantly higher when compared to the protodioscin concentrations in the plant material sampled by the total collection concentrations. The same occurred in August to November, 2014 (months corresponding to the outbreak) when occasion, eight lambs were hospitalized with signs of intoxication. Including clinical recurrences, there were 11 lamb hospitalizations in this period (Table 1).

The forage canopy presented different morphological characteristics that differed according to the time of the year. The samples obtained by the simulated grazing method were represented by growing leaf blades, belonging to the upper herbaceous stratum of the canopy, corresponding to the parts most selected by the lambs during grazing. The leaf blades obtained by the total collection method, after the morphological separation, were characterized by recently expanded or not, and senescence leaf blades.

In May, June and July of 2014 rainfall was respectively $118.00,54.20$, and $119.20 \mathrm{~mm}$. In May and June, the protodioscin concentrations on samples collected by either method were similar. In July, there was a significant difference between the protodioscin concentrations in the samples collected by the two methods. The protodioscin concentration in the samples obtained by simulated grazing remained constant in June and July. However, it was observed that in samples obtained by the total collection method, there was a variation of $0.75 \%-0.24 \%$ in the protodioscin concentrations (Fig.1).

In the months of August-November, 2014 rainfall was respectively $17.20,65.80,19.00$ and $225 \mathrm{~mm}$. At this stage, the protodioscin concentrations of the samples obtained by simulated grazing were significantly higher than those in the samples obtained by total collection. From August to October 2014, the highest concentrations of protodioscin were observed in both collection methodologies (Fig.1).

As of November 2014, when there was an increase in rainfall, there was a drop in the protodioscin concentrations in samples obtained by both collection methods. In December 2014, January and February 2015, rainfall was respectively $364.00,245.80$ and $161.00 \mathrm{~mm}$ and there was no significant difference between protodioscin concentrations in samples obtained by either collection method (Fig.1).

Table 1. Protodioscin concentrations (\%) in Brachiaria spp. samples obtained by the simulated grazing (SG) and total collection (TC) methods

\begin{tabular}{|c|c|c|c|c|c|}
\hline \multirow{3}{*}{ Stages } & \multirow{3}{*}{ Month of collection* } & \multicolumn{2}{|c|}{ Number of Brachiaria- poisoned sheep } & \multicolumn{2}{|c|}{ Method } \\
\hline & & \multirow{2}{*}{$\begin{array}{c}\text { New cases } \\
(\mathrm{n}=8)\end{array}$} & \multirow{2}{*}{$\begin{array}{l}\text { Relapses } \\
(\mathrm{n}=12)\end{array}$} & SG & $\mathrm{TC}$ \\
\hline & & & & \multicolumn{2}{|c|}{ Protodioscin (\%) } \\
\hline \multirow[t]{3}{*}{ Suckling } & May 2014 & & & 0.42 & 0.24 \\
\hline & June 2014 & & & 0.69 & 0.75 \\
\hline & July $2014^{* *}$ & & & 0.68 & 0.24 \\
\hline \multirow[t]{4}{*}{ Rearing } & August2014** & 5 & & 1.61 & 1.14 \\
\hline & September $2014^{* *}$ & 2 & 4 & 1.81 & 0.94 \\
\hline & October $2014^{* *}$ & 1 & 1 & 1.27 & 0.89 \\
\hline & November $2014^{* *}$ & & 6 & 1.15 & 0.67 \\
\hline \multirow[t]{3}{*}{ Finishing } & December 2014 & & & 0.79 & 0.90 \\
\hline & January 2015 & & & 0.68 & 0.74 \\
\hline & February 2015 & & 1 & 1,10 & 1.22 \\
\hline Average & & & & 1.020 & 0.777 \\
\hline Standard deviation & & & & 0.448 & 0.328 \\
\hline
\end{tabular}




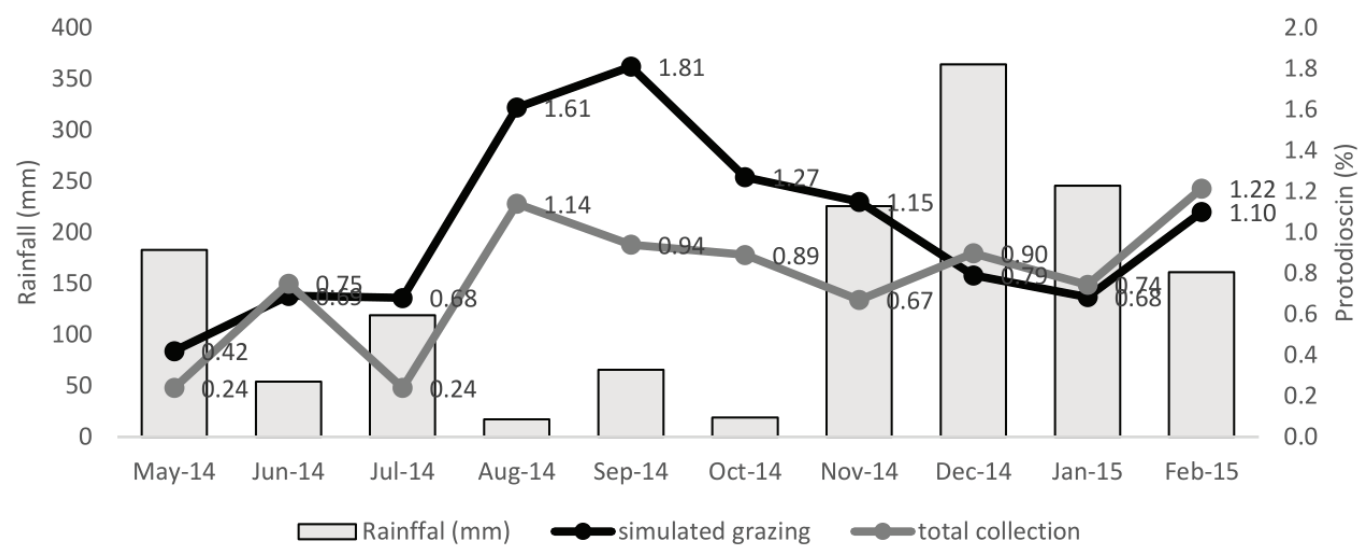

Fig.1. Protodioscin concentrations (\% dry matter) in pastures of Brachiaria spp. from May 2014 to February, 2015. Data gathered through the analysis of samples obtained by the simulated grazing and the total collection methods.

\section{DISCUSSION}

When considering the whole experimental period, there was no significant difference between protodioscin the values obtained by the two methods of collection, demonstrating that both are effective for determining the concentrations of protodioscin in Brachiaria spp. However, from July to November 2014, the protodioscin concentrations values obtained by the simulated grazing method were higher than those obtained by the total collection concentrations. In July, one month before they experience an outbreak of Brachiaria, the lambs were still suckling and allocated to pastures of B. brizantha. The protodioscin concentration measured by the total collection method was $0.24 \%$, whereas that measured by the simulated grazing method was $0.68 \%$. Previous studies have reported outbreaks of $B$. brizantha poisoning in weaned lambs, where protodioscin concentrations ranged from $0.88 \%$ to $0.92 \%$ (Albernaz et al. 2010).

On August 2014 the lambs were weaned and transferred to pastures of $B$. decumbens. The highest protodioscin concentrations were observed from August to November 2014: protodioscin concentrations measured by the total collection method, ranged from $0.67 \%$ to $1.14 \%$, while when measured simulated grazing methods were $1.15 \%-1.81 \%$. An outbreak of Brachiaria-poisoning occurred during this same period, causing the hospitalization of eight lambs and clinical relapses of the toxicosis in 11 lambs. Previous studies have described outbreaks in less than one-year-old lambs, kept in pastures with mixed Brachiaria species or in pastures consisting exclusively of $B$. decumbens; such outbreaks were associated with protodioscin concentrations of $0.30 \%-2.56 \%$ (Mustafa et al. 2012, Porto et al. 2013). The protodioscin concentrations of the current study, measured by both methodologies, are within the concentrations range reported in previous studies which described outbreaks in sheep of the same category. However, those studies do not lend themselves to an adequate comparison, because they applied different forms of plant material collection and different intervals between collections (Mustafa et al. 2012, Porto et al. 2013). Furthermore, they sampled the entire aerial part of the plant (leaf blade, stem + sheath, and senescent material) at intervals of 7-15 days.

Although there is a great deal of information on the protodioscin concentrations and the different methods of plant collection, there were no previous studies comparing different methods for Brachiaria spp. collection for protodioscin levels determination, which at the same time associate these concentrations to the clinical manifestations of Brachiaria poisoning. Also, the feeding habits of sheep, which are more selective when compared to cattle, were not taken into account in previous studies (De Paula et al. 2009).

During the period of an outbreak of Brachiaria poisoning (August-November 2014) the samples of leaf blades acquired by the total collection method were formed by expanded or senescent leaf blades. On the other hand, the samples obtained by the simulated grazing consisted of growing or newly expanded leaf blades, belonging to the upper stratum of the canopy, corresponding to the parts most selected by the lambs. From these results, it is possible to demonstrate that the protodioscin concentrations in the growing leaf blades, which are more selected by the sheep, are significantly higher than the concentrations belonging to other parts, which tended to be less grazed. Thus, it can be stated that the collection by the methodology of simulated grazing allows a closer estimate of the concentrations of protodioscin responsible for the occurrence of clinical cases of intoxication. In other words, the occurrence of clinical cases and relapses concomitantly with the highest concentrations of protodioscin in growing leaf blades is related to grazing behavior of the lambs (De Paula et al. 2009, Faccin et al. 2014).

Samples obtained from both methodologies yield results with differences and similarities, which varied according to the period of the year. The highest protodioscin concentrations in samples from both methodologies were observed in the dry season, periods with lower rainfall (July-November 2014). From July to November 2014, there was a decrease in the production of new leaf blades and increase of leaf blades fibrous fraction. In the total collection methodology, there was a predominance of samples with senescent material which differed from that obtained by the selective grazing method, which had a predominance of growing or expanded leaf blades. In the dry season, plant moisture decreases and dry matter content increases consequently the protodioscin concentrations of increase in the growing leaflets commonly presented in samples obtained by the selective grazing method. As the samples obtained by total collection method consisting, almost in their entirety, of stems and senescent leaves, the 
protodioscin concentration of the toxic principle decreased. As of November 2014, parallel with the increase in rainfall, there was an increase in growing leaf blades in the samples obtained by the total collection method.

During December 2014-2015, there was an increase in rainfall. An increment of forage mass and a higher prevalence of growing leaf blades were observed in the samples obtained by the total collection method, i.e., a sample similar to what the sheep selected in the selective grazing. The values of protodioscin were then approximately the same in samples gathered by both methods, because in both the presence of the same fraction prevailed and corresponded to new leaf blades not yet expanded. As these leaf blades have a high moisture content, the concentrations of protodioscin expressed as dry matter decreased because the fibrous fraction in which the toxic principle is associated was low.

Although the highest concentrations of protodioscin in the samples obtained by of simulated grazing coincided with the period of appearance of the clinical cases, it was not possible to determine the toxic protodioscin concentration for lambs due to the different degrees of disease observed in the poisoned sheep. In the present study, the cases occurred only in lambs originating from a sensitive herd, a progeny from ram and ewes showing clinical signs of intoxication in a given time (Pupin et al. 2016). The existence of varying degrees of sensitivity is related to genetic factors and the adaptation of sheep to the consumption of Brachiaria spp. (Faccin et al. 2014, Castro et al. 2018, De Melo et al. 2018).

\section{CONCLUSION}

Both methodologies used are adequate for determining the protodioscin concentration in Brachiaria decumbens in the pasture. However, specifically in periods of ongoing outbreaks of Brachiaria poisoning in sheep, the simulated grazing method is more efficient, as it more accurately depicts the amount of protodioscin ingested by the sheep.

Acknowledgments.- The authors are grateful to the "Fundação de Apoio ao Desenvolvimento do Ensino, Ciência e Tecnologia do Estado de Mato Grosso do Sul" (FUNDECT). This study was carried out with the support of the "Coordenação de Aperfeiçoamento de Pessoal de Nível Superior" (CAPES), Brazil, Financing Code 001. The author Ricardo A.A. Lemos has a fellowship from "Conselho Nacional de Desenvolvimento Científico e Tecnológico" (CNPq), Brazil (309074/2018-5).

Conflict of interest statement.- The authors have no competing interests.

\section{REFERENCES}

Albernaz T.T., Silveira J.A.S., Silva N.S., Oliveira C.H.S., Reis A.S.B., Oliveira C.M.C., Duarte M.D. \& Barbosa J.D. 2010. Fotossensibilização em ovinos associada à ingestão de Brachiaria brizantha no estado do Pará. Pesq. Vet. Bras. 30(9):741-748. <http://dx.doi.org/10.1590/S0100-736X2010000900006>

Brum K., Haraguchi M., Lemos R.A.A., Riet-Correa F. \& Fioravanti M.C. 2007. Crystal-associated cholangiopathy in sheep grazing Brachiaria decumbens containing the saponin protodioscin. Pesq. Vet. Bras. 27(1):39-42.<http:// dx.doi.org/10.1590/S0100-736X2007000100007>
Castro M.B., Gracindo C.V., Landi M.F.A., Cabral Filho S.L.S., Resende Filho N.J., Lima E.M.M. \& Riet-Correa F. 2018. Sheep adaptation management, and investigation of inherited resistance to prevent Brachiaria spp. poisoning. Small Rumin. Res. 158:42-47. <http://dx.doi.org/10.1016/j. smallrumres.2017.12.001>

Cook C.W. 1964. Symposium on nutrition of forages and pastures: Collecting Forage samples representative of ingested material of grazing animals for nutrition studies. J. Anim. Sci. 23(1):265-270. <http://dx.doi.org/10.2527/ jas1964.231265x>

De Melo G.K.A., Ítavo C.C.B.F., Silva J.A., Monteiro K.L.S., Faccin T.C., Pupin R.C., Heckler R.F., Ítavo L.C.V., Silva P.C.G., Leal P.V. \& Lemos R.A.A. 2018. Poisoning by Brachiaria spp. in suckling lambs supplemented and unsupplemented in a creep-feeding system. Small Rumin. Res. 158:30-34. <http://dx.doi. org/10.1016/j.smallrumres.2017.11.014>

De Paula E.F.E., Stupak E.C., Zanatta C.P., Poncheki J.K., Leal P.C. \& Monteiro A.L.G. 2009. Comportamento ingestivo de ovinos em pastagens: uma revisão. Revta Trop., Ciênc. Agr. Biol. 4(1):42-51.

Faccin T.C., Riet-Correa F., Rodrigues F.S., Santos A.C., Melo G.K.A., Silva J.A., Ferreira R., Ítavo C.C.B.F. \& Lemos R.A.A. 2014. Poisoning by Brachiaria brizantha in flocks of näive and experience sheep. Toxicon 82:1-8. <http:// dx.doi.org/10.1016/j.toxicon.2014.02.008><PMid:24561120>

Ganzera M., Bedir E. \& Khan I.A. 2001. Determination of steroidal saponins in Tribulus terrestres by reversed phase high-performance liquid chromatography and evaporative light scattering detection. J. Pharm. Sci. 11(90):1752-1758. <http://dx.doi.org/10.1002/jps.1124><PMid:11745732>

Goes R.H.T.B., Mancio A.B., Lana R.P., Valadares Filho S.C., Cecon P.R., Queiroz A.C. \& Costa R.M. 2003. Avaliação qualitativa da pastagem de capim TannerGrass (Brachiaria arrecta) por três diferentes métodos de amostragem. Revta Bras. Zootec. 32(1):64-69. <http://dx.doi.org/10.1590/S151635982003000100008>

INMET 2015. Instituto Nacional de Meteorologia, Ministério da Agricultura Pecuária e Abastecimento. Available at <www.agraer.ms.gov.br/cemtec> Accessed on Mar. 28, 2015.

McMenniman N.P. 1997. Methods of estimating intake of grazing animals. Anais do XXXIV Simpósio sobre tópicos especiais em zootecnia, Reunião Anual da Sociedade Brasileira de Zootecnia, Juiz de Fora, MG, p.131-168.

Mustafa V., Moscardini A.R.C., Borges J.R.J., Reckziegel G.C., Riet-Correa F. \& Castro M.B. 2012. Intoxicação natural por Brachiaria spp. em ovinos no Brasil Central. Pesq. Vet. Bras. 32(12):1272-1280. <http://dx.doi. org/10.1590/S0100-736X2012001200010>

Porto M.R., Saturnino K.C., Lima E.M.M., Lee S.T., Lemos R.A.A., MarcolongoPereira C., Riet-Correa F. \& Castro M.B. 2013. Avaliação da exposição solar na intoxicação experimental por Brachiaria decumbens em ovinos. Pesq. Vet. Bras. 33(8):1009-1015. <http://dx.doi.org/10.1590/S0100736X2013000800011>

Pupin R.C., Melo G.K.A., Heckler R.F., Faccin T.C., Ítavo C.C.B.F., Fernandes C.E., Gomes D.C. \& Lemos R.A.A. 2016. Identification of lamb flocks susceptible and resistant against Brachiaria poisoning. Pesq. Vet. Bras. 36(5):383-388. <http://dx.doi.org/10.1590/S0100-736X2016000500005>

Riet-Correa B., Castro M.B., Lemos R.A.A., Riet-Correa G., Mustafa V. \& Riet-Correa F. 2011. Brachiaria spp. poisoning of ruminants in Brazil. Pesq. Vet. Bras. 31(3):183-192. <http://dx.doi.org/10.1590/S0100-736X2011000300001>

Weir W.C. \& Torell D.T. 1959. Selective grazing by sheep as shown by a comparison of the chemical composition of Range and pasture forage obtained by hand clipping and that collected by esophageal-fistulated sheep. J. Anim. Sci. 18(2):641-649.<http://dx.doi.org/10.2527/jas1959.182641x> 